\title{
From Chongzhen lishu 崇禎曆書 to Tengri-yin udq-a and Rgya rtsis chen mo
}

\author{
Leonard W.J. van der Kuijp
}

Beginning with the visits to the Tibetan area by the Portugese Jesuit priests A. de Andrade (1580-1634) and M. Marques (d.1640s) in the 1620s, regions dominated by Tibetan religion and culture were visited by a number of Catholic priests belonging to several different orders, men of the cloth who were ostensibly in search of souls that, in their view, needed to be saved. One undoubted high point among these contacts is the well-documented stay in Central Tibet of the Italian Jesuit priest I. Desideri (1684-1733) during the years $1715^{-1721 .}$ In his recent splendid book, T. Pomplun (2010) included a compelling narrative of this priest's encounters with the doctrines of the $d G$ e lugs pa school of Tibetan Buddhism. ${ }^{1}$ It will no doubt be fruitful to read this rewarding volume together with the larger-scale study of Wu Kunming 伍昆明 (1992), which is primarily based on a very judicious use of a good number of archival documents in a variety of European languages. ${ }^{2}$ Sweet's highly readable translation of Desideri's mission makes equally compelling reading, as does the recent, slim reprint of a number of Desideri's letters and personal papers edited and translated by H. Hosten, s.J. ${ }^{3}$ Amazingly, when one considers his relatively short stay in the Tibetan area, Desideri apparently wrote several treatises in Tibetan, a good number of which are now available in an Italian translation by G. Toscana, s.J. However, his major work contra Buddhism, the so-called Questions on Rebirth and Emptiness of perhaps 1731 (Pomplun 2011, 402ff.), ${ }^{4}$ has yet to be edited and studied.

1 See also the fine bibliographical and analytical survey of Desideri's Tibetan writings in Pomplun (2011); and for another recent contribution to this theme, see Sweet (2006).

2 My thanks go to Prof. Zhang Changhong of Sichuan University for reminding me of the existence of this important work, which is not registered in Pomplun's bibliography.

3 See, respectively, Sweet (2010) and Hosten (2011). The latter was originally published in the Journal of the Asiatic Society of Bengal (1938), 567-767.

4 I have not seen the manuscript, but Pomplun cites its title: $m$ Go skar bla ma i po li do zhes bya ba yis phul ba'i bod kyi mkhas pa rnams la skye pa snga ma dang stong pa nyid kyi lta ba'i sgo nes zhu ba. This should be corrected to mGo dkar bla ma i po li do zhes bya ba yis [or better:

(C) LEONARD W. J. VAN DER KUIJP, 2016 | DOI 10.1163/9789004316256_007

This is an open access chapter distributed under the terms of the Creative Commons Attribution-

Noncommercial 3.0. Unported (CC BY-NC 3.0) License. 
A band of Jesuit priest-astronomers such as Matteo Ricci (1552-1610), Johann Schreck (1576-1630) and Giacomo Rho (1583-1638), who were followed by Johann Adam Schall von Bell (1591-1666) and Ferdinand Verbiest (1623-88), together with their Chinese acolytes and converts, introduced Western astronomy and mathematics into China during the late Ming and early Qing. The story of their treatises and translations is well known and its broad contours have been well surveyed in a good number of publications. ${ }^{5}$ These translations introduced their newly found audience to the astronomy of Tycho Brahe (1546-1601) and Johannes Kepler (1571-1630), in particular. Empire and the cosmopolitanism of the Qing court had an interesting, unintended consequence, namely, that a small band of Mongols and Tibetans who were active at the imperial court were also able to gain access, through the Chinese translations, to these collections of writings on Western astronomy. The source for these was the compendium titled Chongzhen lishu 崇禎曆書, Calendrical Treatise of the Chongzhen Reign, of roughly 1635 , the publication of which was supervised by Xu Guangqi 徐光啟 (1562-1633) and Li Tianjing 李天經 (1579-1659). ${ }^{6}$ Its pendant of 1645, the Xiyang xinfa lishu 西洋新法曆書, Calendrical Treatise Based on the New Western Methods, was issued by Schall von Bell. Both compendia consist of Chinese translations and reformulations of a series of texts on astronomy, a number of individual items of which have so far remained unidentified, that were written in part by the Jesuit scholar-priests. In 1669, Verbiest followed the reissue of the Xiyang xinfa lishu with a tract titled Xinfa suanshu 新法算书, Mathematics Based on New [Western] Methods, that was compiled and later published in 1700 by order of the Kangxi emperor. Earlier, in 1656, Schall von Bell had compiled the Jianyao lishu 簡要曆書, Simplified Calendrical Treatise, as a kind of guidebook to the much more voluminous Xiyang xinfa lishu, for the Shunzhi 順治 emperor (r. 1644-1661). His son Kangxi, too, took a keen personal interest in calendrical astronomy - at one point he wrote, not altogether unexpectedly, that "calendrical methods are linked to essential affairs of State" - and had made serious studies of the subject as well as of mathematics with Verbiest and other Jesuits (Jami 2012, 61, 73ff., 139ff.). The Tibetans became aware of what appears to have been the Xinfa suanshu

zhes bya bas] phul ba'i bod kyi mkhas pa rnams la skye ba snga ma dang stong pa nyid kyi lta ba'i sgo nas zhu ba.

5 Aside from a massive amount of Chinese scholarship on this topic, Needham and Wang (1970, 437-61) still gives an admirable overview, as does Sivin (1973) [= Sivin (1995)], and also Martzloff (1993-1994). For a detailed study of the Kangxi 康熙 period, 1662-1722, see now Jami (2012) and its excellent bibliography.

6 For this work and its successors, see Chu (2007) and Pen Nai (2009). 
through their Mongol co-religionists as well as by their direct contact with the Kangxi court. But they were not privy to the innovations and refinements that were later introduced by such men as Jean-François Foucquet, S.J. (1665-1741) in 1712 and, in any event, these were virtually of no consequence for the preparation of calendars (Jami 2012, 284-311). The compendium was to have a lasting effect on traditions of Tibetan calendar making in the Amdo area.

In their survey of the introduction of Western calendrical astronomy in the Tibetan cultural area, Huang Mingxin 黄明信 and Chen Jiujin 陈久金 indicated that portions of the Xinfa suanshu were translated into Mongol in 1711 by order of Kangxi, that is, 11 years after the printing of the Chinese text. ${ }^{7}$ And they signalled the existence of a xylograph of this Mongol translation in the Beijing National Library. My copy of the xylograph, courtesy of the kind offices of Mr Yumpa and his colleagues, does not have a title page, but the 13-page Preface has the following heading: Qitad-un jiruqai-yin sudur eče mongrolčilen orcizuluysan jiruqai-yin [orusil], that is, The Mongol Translation from the Chinese Book on the Mathematical Astronomy. After a preamble, we have, as per protocol, two passages that are elevated from, that is, that are placed above, the upper margin of the main body of the text: namely, a reference to Kangxi,

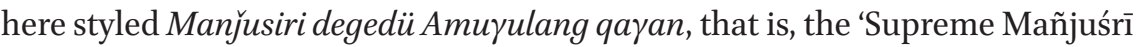
Kangxi Emperor' and an official decree as well as a listing of the names of various individuals, scholars, artists [for drawing the planetary constellations and star maps], and officials, who took part in the translation project (orči $i u l u \gamma c ̌ i$ kelemürči-ün ner-e). Thus, a consortium of scholars who were able to translate Mongol (mongrol bičig), Tibetan (töbed...), and Chinese (kitad ...) written documents were involved in this project that may (but only may, since evidence for this appears to be lacking) have been nominally headed by Rje btsun dam pa Quturtu I Blo bzang bstan pa'i rgyal mtshan (1635-1723) of Urga [= Ulaan Baatar]. As indicated by his biographer and friend Jaya Panditita Blo bzang 'phrin las dpal bzang po (1642-1708), Rje btsun dam pa and Kangxi enjoyed very close relations. They had been in indirect contact since 1688 when rJe btsun dam pa had requested the court for protection against the Jungar Mongols, but their first recorded face-to-face meeting took place some three years later, in May of 1691, in mTsho bdun [Mon. Doluyan nayur = Dolonor], in Čaqar. ${ }^{8}$ And they seem to have taken to one another immediately. Being a witness to the growth of their relationship, Jaya Pandita writes that not only

7 Some of the details that follow are taken in part from Huang and Chen $(1987,316-17,599-605)$.

8 For this and what follows, see Jaya Paṇita Blo bzang 'phrin las dpal bzang po (1981a, 70a-74a) and Jaya Pạ̣dita Blo bzang 'phrin las dpal bzang po (1981b, 479-517). Their first meeting was occasioned by the conclusion of a tribute treaty between the Qalqa Mongols and the Qing 
did the emperor pay him personal visits in his private quarters (gzings/gzims gur) - this would contravene well-established imperial protocol and must have occasioned some frowns on the foreheads of his Chinese advisors - but also that he himself had heard the emperor say twice or thrice that he held no lama in higher esteem than his [or: their] teacher! One wonders, of course, what he would have written had he been asked about Kangxi's relationship with lCang skya II Ngag dbang blo bzang chos ldan (1642-1714), whom the emperor had awarded with the very substantial title of National Preceptor (Ch. guoshi) title in 1705 while visiting Dolonor! (See the narrative in Sagaster $(1967,281-2$.) Even if it is still far from clear exactly what kind of privileges this title may have carried with it, aside from the obvious increase in the prestige of its holder, rJe btsun dam pa was never given this title and the privileges it may have entailed.

It now turns out that this blockprint was published in printed book-form in Inner Mongolia under the title of Tengri-yin udq-a, Essence of Heaven (Čeden 1990). ${ }^{9}$ With his usual resourcefulness, my student Mr Jo Sokhyo 조석효 [曹锡孝], ever the 'library cormorant', to borrow a memorable phrase from Samuel T. Coleridge, was able to secure copies of this work - I thank him for kindly providing me with one of these - that, given its topic and date of publication, really should no longer have been available for purchase. This collectanea was also translated into Tibetan, and Mr Jo is studying this compendium for his doctoral dissertation where he will deal with its various linguistic incarnations with a special focus on the section that deals with the calculation of solar eclipses (rishi 日食, naran bariqu, nyi 'dzin).

Simply titled rGya rtsis chen mo, Great Chinese Astronomy, the Tibetan translation of the Mongol version appears to date from circa $1714-15 \cdot{ }^{10}$ The bilingual pagination with the Tibetan numbering on the left-hand and the Chinese on the right-hand side of the page no doubt has its origin in the fact that Chinese and not Tibetan artisans were responsible for carving the printing blocks. Indeed, being ignorant of Tibetan, carving Chinese-style pagination on the blocks was the only way in which they could keep track of what they were

court. Jean-François Gerbillon, s.J. (1654-1707) provided an eyewitness account of this event, for which see the reference in Charleux 2006, 80, n. 68.

9 Its Chinese title is Tianwen yuanli 天文原理. This work was not used or cited in the otherwise very substantial study of Baumann (2008).

1o Here I should like to thank Mr Yumpa for having so generously shared with me his copy of this translation, which has yet to be published. Karmay $(2003,1999)$ has the following entry at E.039: rgya nag gsar rtsis kyi stong thun 'gyur byang ma 9ff. Though the Tibetan phrase can be rendered as "translation's colophon of a miscellany anent the new Chinese astrononomy," the fact that a young Chinese astronomer/astrologer (rtsis pa rgya phrug) had a stake in it makes it pretty much unlikely that this refers to our text. 
carving. We have already come across this custom of dual pagination in the Tibetan xylographs from printing blocks that were carved in Dadu 大都, the winter capital of the Yuan dynasty. ${ }^{11}$ Again, Yum pa was able to locate a xylograph of the Great Chinese Astronomy from these blocks among the vast library holdings of the Potala in Lhasa. ${ }^{12}$ The result of the labours of a team of bilingual Mongol scholars (including, so it would appear, the rJe btsun dam pa himself) survives in a xylograph from printing blocks that were carved in Beijing in 1715, the 54th year of Kangxi's reign. Still uncomfortable with the geocentric model of the Galilean solar system, these seventeenth-century Jesuit astronomers had adopted the geoheliocentric or Tychonic model of the solar system as advocated by Brahe and were of course also quite familiar with Kepler..$^{13}$ That being the case, it is still surprising to see mention of the names of both astronomers in these compendia ${ }^{14}$ that also contain numerous glosses in smaller lettering. Independently titled 'Jam dbyangs bde ldan rgyal pos mdzad pa'i rgya rtsis bod skad du bsgyur ba'i spar byang, Print Colophon of the Chinese Calendrical Astronomy, Written by the Mañjuśri Emperor Kangxi, which was Translated into Tibetan, the concluding colophon of the Tibetan translation in three folios is as lengthy as it is instructive. My student Mr Jo will present an analysis of it, as he will deal with the particulars of the Mongol translation.

A key point: as is to be expected, traditional Tibetan culture makes no distinction between astrology and astronomy. In Europe, a distinction between the two was apparently first made as late as the Renaissance and, even so, a number of bona fide European astronomers like, for example, Kepler continued not merely to take an interest in but actually also to write on astrological subjects. In the Indian subcontinent as well in Tibet, astronomy with its rigorous mathematics and astrology fell under the rubric of rtsis rig pa (*jyotihvidya $)$, that is, what can be called 'astral science', and it was in turn included in the so-called 'eighteen domains of knowledge' (rig gnas chung ba bco brgyad),

11 For some of these xylographs, see van der Kuijp (2013, 127-8, nos. 33-4), and the literature cited there.

12 See Yum pa $\left(1998,55^{6-67}\right)$.

13 It is worthy of note that there were other Jesuits who introduced the competing heliocentric astronomy, for which see Shi (2007).

14 See the Rgya rtsis chen mo, vol. pa, fol. 1b ('og) / Juan 21, fol. 1b (xia): "Kepler [with a gloss:] 'was a friend of Ti go [= Tyho, vdK]']." (ke pe el [with a gloss: ti go'i grogs po yin /) - half forgotten, Mr Yumpa pointed this passage out to me long ago when he was a HarvardYenching coordinate scholar in the year 2009. See now also the parallel Mongol text of the Qitad-un yiruqai-yin sudur in Čeden (1990, 690): ke pi lel [with a gloss: ti go nökür yin bolai:]. There is of course hardly any question that the Mongol and the Tibetan transcriptions go back to Chinese Kebai'er 刻白爾 for Kepler and Tigu 弟谷 for Tycho. 
an enumeration for which the very early Vinayavibhanga may very well be the locus classicus (see sDe dge (1991, vol. 51, no. 4357 [\# 4352], 406/iff. [Co, 20obff.]), as quoted in Khams sprul Iv bsTan 'dzin chos kyi nyi ma $(1976,11)$. The Tibetan term for astrologer/astronomer is rtsis $p a$, which literally means "one who calculates/computes" and, to my knowledge first attested for the fifteenth century, the court-astrologer at the Phag mo gru court was called bla $r t s i s ~ p a$, a title that came to be employed for several centuries. ${ }^{15}$

The libraries of Bla brang bkra shis 'khyil monastery in that portion of Amdo / mDo smad that is located in Gansu Province also reportedly contain a witness of this work, but it is as yet unclear whether this is a xylograph or a manuscript copy. ${ }^{16}$ In any event, I suspect that it is currently located in the monastery's E vam chos 'khor gling, that is, its Dus 'khor [Kālacakra] Seminary (grwa tshang). According to his biographer and disciple Gung thang III dKon mchog bstan pa'i sgron ma (1762-1823), dKon mchog 'jigs med dbang po (1728-1791), alias 'Jam dbyangs bzhad pa'i rdo rje II, had founded this seminary in 1763 at the instigation of Pan chen Lama III [or VI] dPal ldan ye shes (1738-1780) (see Gung thang III dKon mchog bstan pa'i sgron ma $(1971,158)$ [= 1990, 143-144]; see also Brag dgon Zhabs drung dKon mchog bstan pa rab rgyas $(1982,523)$ ). The third volume of the collected writings of Blo bzang sbyin pa (1918-after 2003), alias Tshangs sras bzhad pa'i blo gros and Smad sog Badzra, is devoted to the study of the calendar that is based on the astronomy that we find in this compendium (Blo bzang sbyin pa 2003) ${ }^{17} \mathrm{He}$ is [or was] institutionally affiliated with this seminary. And the same holds for another recent work on the calendar that was written in 1985 by Shes rab chos 'phel, alias Mi pham dbyangs can dgyes pa'i blo gros, who was also connected with Bla brang's Dus 'khor Seminary (Shes rab chos'phel 1989). And Huang Mingxin, whose Tibetan name is bSod nams rgya mtsho, writes that he had studied Chinese astral science

15 Schuh $(2012,1497)$ renders bla rtsis $p a$ as 'Divinationsmeister'. This is found in the last volume of his four-volume compendium of the secondary literature on the subject in Japanese, German, French and English. I thank him for kindly providing me with a copy of this useful and remarkable collection. But his 'Divinationsmeister' is too one-sided and thus a trifle misleading, since a bla rtsis pa was also engaged in computational astronomy and calendar making. Indeed, his definition of $r$ sis $p a$ on p. 1541 is much more inclusive.

16 Ascribed to 'Jam dbyangs bDe ldan rgyal po, that is the Kangxi ( $b$ de ldan $=$ kangxi $=b d e$ skyid) Emperor himself, the titles of the individual chapters of the text are given in Grags pa $(1985,42-44)$. The work in which this entry is found is a title catalogue of the holdings of the libraries of Bla brang bkra shis 'khyil monastery sans the personal library of the 'Jam dbyangs bzhad pa'i rdo rje re-embodiments.

17 The author of several studies of the Sanskrit grammer of the Sarasvatīyākarana and prosody, Blo bzang sbyin pa spent some 22 years in jail, regaining his freedom in 1979. 
(rgya rtsis) with the astronomer (rtsis rams pa) bSam grub rgya mtsho of the Kyai rdor gsangs sngags dar rgyas gling Seminary of Bla brang bkra shis 'khyil and that he benefitted also from the historian of science Khren ci'u cin, that is, Chen Jiujin (Huang and Chen 1987, 619). ${ }^{18}$ Lastly, 'Jam dbyangs bzhad pa'i rdo rje IV Skal bzang thub bstan dbang phyug (1856-1916) wrote a short piece on the chronology of Buddhism (bstan rtsis) according to the Rgya rtsis chen po [= $m o]$. It will be worth our while to examine this little work a little more closely. ${ }^{19}$

After a brief preamble on earlier emperors of China, 'Jam dbyangs bzhad pa'i rdo rje IV states that the historical Buddha was born in the 26th regnal year of Tse'u dbang (<Ch. Zhao Wang 照王), the fourth emperor of the Zhou Dynasty, who reigned from circa 995 to 977 or from circa $977 / 975$ to 957 . To be sure, we find this already in the anonymous account of the famous sandalwood statue that was translated from Chinese into Uyghur by a certain Am chang and then, evidently in a water-female-pig year (1263), from this Uyghur version into Tibetan by a certain Danasi. ${ }^{20}$ Somewhat artificially titled Tsan dan gyi sku rgya nag na bzhugs pa'i byon tshul, Origin of the Sandalwood Statue which Resides in China, and oddly included under the rubric of Rgyud 'grel in two of the later xylograph editions of the Tanjur-canon - it is only found in the Tanjur editions of Bejing (1724-1738) and sNar thang (1741-1742) as well as in the so-called Golden Tanjur manuscript (c. 1733-c. 1741) - we do not encounter its listing in the available fourteenth- and fifteenth-century catalogues of the Tanjur, not even those from the pen of Karma pa III Rang byung rdo rje $\left(1284^{-1339}\right)^{21}$ whose monastery, mTshur phu, was part of Tshal pa myriarchy

18 bSam [']grub rgya mtsho must be identified as the author of the two-volume work on astral science, for which see bSam grub rgya mtsho (1992).

19 What follows is based on 'Jam dbyangs bzhad pa'i rdo rje IV Skal bzang thub bstan dbang phyug (nd).

20 For further details surrounding the account of the sandalwood statue, see Pelliot (1914, 188-90); on the Kangxi stele inscription of 1721, MacDonald (1963, 77ff.), and more recently Sørensen $(1986,241-51)$ and Sørensen (1994, 78, 500-506). See also below.

21 The text is registered in the 1688 catalogue of the Beijing Tanjur that was allegedly compiled by a venerable monk (ban rkan [= rgan]) of Za hor, gDong drug bsnyems pa'i lang tsho and scribed by the 'master of dance' ('chams dpon) Ngag dbang dkon mchog; see gDong drug bsnyems pa'i lang tsho $(1983,209)$. The identification 'old, venerable monk (ban rkan [= rgan]) of Za hor' is frequently used by Dalai Lama v Ngag dbang blo bzang rgya mtsho (1617-82), but nowhere does he mention the name gDong drug bsnyems pa'i lang tsho in his autobiography. On the other hand, he does register there a 'Chams dpon Ngag dbang dkon cog [= mchog], for which see Dalai Lama v Ngag dbang blo bzang rgya mtsho (1991, 433, 438). A 'New (gsar ba) gDong drug bsnyems pa'i lang tsho' figures in the colophon of sDe srid Sangs rgyas rgya mtsho's (1653-1705) 1699 interlinear exegesis 
(khri skor) that Tshal pa Kun dga' rdo rje (1309-64) governed from 1323 to circa 1350. Titled Deb ther dmar po, Red Book, the latter's influential chronicle, of which one recension contains a passage that is dated as late as 23 March ${ }_{1363}$, includes a/the narrative of this statue that was apparently referred to in a work that he calls a Rgya nag po'i yig tshang, a Chinese Document. We are informed that this Document was translated into Tibetan by one Shes rab ye shes, who, we are told, had been a disciple of Sa skya Pandita (1182-1251) and who was an erstwhile abbot (mkhan po) of Byang ngos [= Liangzhou 涼州, present-day Wuwei 武威], Gansu Province (see Tshal pa Kun dga' rdo rje 1981, 11-12). Here, Byang ngos might indicate any one of the so-called four monasteries of Liangzhou (lang gru sde bzhi). These are: Lha khang sde (Ch. Jinta si 金塔寺) to the south; Padmo'i sde to the west; Rgya mtsho'i sde to the north; and Sprul pa'i sde (Ch. Baita si 白塔寺) to the east. ${ }^{22}$ All are located within a relatively short distance of Wuwei and all were founded by Sa skya Pandita. In his account of the influential Zi na family and their "home" monastery of Zi na bsam grub gling that is found in the area that would later be dominated by sKu 'bum monastery, Brag dgon Zhabs drung notes a certain Zi na mKhan po Shes rab ye shes dpal bzang po, who was apparently related to a certain Zi na Tse 'jo. We do not know whence he obtained this important narrative, but it definitely bears paraphrasing. While he does not quite explain how this came to pass, he writes that $\mathrm{Zi}$ na Tse 'jo was virtually raised as the fourth son of Tolui-noyan (1192-1232), Činggis Qan's (?1162-1227) youngest son, and his wife Zo ro ta [Sorqaqtani] (d. 1252). ${ }^{23}$ According to his narrative, the third son was none other than Qubilai, and it was he who had requested his uncle Köden Qan for Sa skya Pandita to be his chaplain. Köden only partly acquiesced to this request and gave him the latter's young nephew 'Phags pa Blo gros rgyal mtshan $\left(1235^{-1280}\right)$. Even if the narrative appears to be somewhat flawed

of Dalai Lama v's commentary on the Kāryāadarśa; see sDe srid Sangs rgyas rgya mtsho (1996, 651), and he is none other than the sDe srid himself. But I am afraid that I cannot [?yet] identify the person who was the original gDong drug bsnyems [or snyems] pa'i lang tsho. Given the fact that he hid Dalai Lama v's passing for more than a decade, it is possible that this catalogue was in fact ghost-written by him.

22 For these, see Dor zhi (1988, 1-58); Brag dgon Zhabs drung dKon mchog bstan pa rab rgyas $(1982,139-47 ; 1989,133-43)$. For a study of this region and the monastery where the Mongol prince of the blood Köden Qan and Sa skya Paṇdita met, see now Fan and Shui (1997) and (2009). I do not have access to the original Chinese text. For the specifics of the four monasteries, see Fan and Shui (2009, 279-308).

23 For what follows, see Brag dgon Zhabs drung dKon mchog bstan pa rab rgyas (1982, 166-7; 1989, 162). To be sure, Tolui-noyan and Sorqaqtani had ten sons, of which Qubilai was in fact the fourth; see Boyle (1971, 159-62). 
chronologically as well as factually, it then continues with Qubilai ordering 'Phags pa to receive his full ordination as a monk in Central Tibet, which we know from other sources to have taken place in 1255. 'Phags pa did not travel alone. He was accompanied by an escort that included a certain Zi na mKhan po Shes rab ye shes dpal bzang po, who, as his name in religion already suggests, was ordained in the lineage that Śākyaśrībhadra (1127-1225) had founded in 1204 (Heimbel 2013). Once in Central Tibet, Zi na Mkhan po ensured that many large and smaller religious institutions benefitted from 'Phags pa's return and gifted them with many goods. When they returned to one of the two Yuan dynasty capital cities (rgyal khab), Qubilai and 'Phags pa became his patrons (yon mchod), ${ }^{24}$ being impressed by the way in which he had been able to handle the affairs of the 'two domains' (lugs gnyis), the religious and the secular. They asked him what he might wish for, to which he replied. As a result, they offered him competence over a number of areas and religious institutions and gave him a document to this effect that included the right to levy corvée labour ('u lag bka'shog bcas;). The areas comprised: Shar Tsong kha, Su rgan, Khri kha, sPen thog, gDung khang, 'Ga Gam cu (?< Ch. Ganzhou 甘州), Bhi ti sde (<Ch. Baita si 白塔寺) in Byang ngos, Ched gsum sde, Khang [g]sar sde, La song sde, and Rin chen gling. And

mchod yon so so nas mu tig gi 'ja' sa re re dang / zon ju dben gyi rtsa ba'i dben șii las ka gnang /

...the patronized (mchod) [= 'Phags pa] and patron (yon) [= Qubilai] each gave him an edict adorned with pearls and the position of the basic Director (dben și < Ch. yuanshi 院使) of the Office of Buddhist and Tibetan Affairs (zon ju $[n g]$ dben $<$ Ch. xuanzhengyuan 宣政院). ${ }^{25}$

Aside from the mKhan po Shes rab ye shes, Tshal pa also mentions a Mi nyag Tsen tse Shes rab ye shes in connection with the historical sketch of Xixia 西夏 that he included in his chronicle (see Tshal pa Kun dga' rdo rje 1981, 28). The toponym 'Mi nyag' indicates that this Shes rab ye shes was in one way or another associated with Xixia, but the import of 'Tsen tse' is a bit of a problem

24 For this meaning of mchod yon, that is, here, mchod gnas [='Phags pa] and yon bdag [= Qubilai], see Seyfort Ruegg (1991, 442ff.); see also Seyfort Ruegg (1995, 41).

25 For Tibetan zon ju dben, Brag dgon Zhabs drung dKon mchog bstan pa rab rgyas (1989, 162) has xuanjiyuan 宣濟院, a department that I have not found attested elsewhere. The Imperial Preceptor and 10 directors headed the Office of Tibetan and Buddhist Affairs; see Farquhar (1990, 153-7). 
and I am unable to come up with a convincing solution of its probable Chinese antecedent ${ }^{26}$ as I am of the ethnic identity of this man, if he be indeed different from the Shes rab ye shes of the Zi na clan.

The internal evidence of this narrative in the Chinese Document as well as in the Origin of the Sandalwood Statue which Resides in China suggests that the water-female-pig year roughly corresponds to the year 1263. Further, the Origin of the Sandalwood Statue which Resides in China indicates that its contents were based on an elusive historical work titled Cung. According to their narratives, the historical Buddha was born on the eighth day of the fourth month of a wood-tiger year and when he passed away [into nirvana] in the waterfemale-pig year (c. $750 \mathrm{BC}$ ), 2013 years had elapsed up to the year of 1263. But the text's Anno Nirvanae of $c .750$ ВС was not without its problems and was taken to task by a number of Tibetan scholars in their quest to ascertain the exact date of the Buddha's passing. One of these was 'Gos Lo tsā ba gZhon nu dpal (1392-1481). He first quotes this chronology in his rTsis la 'khrul pa sel ba, Eliminating Errors in Calendrical Calculations, of 1442/3 and then curtly dismisses its veracity with the remark that it was merely a hypothesis (dam bca' tsam) without any supporting argument or evidence (see 'Gos Lo tsā ba gZhon nu dpal $1466,15 \mathrm{~b}-16 \mathrm{a}, 2 \mathrm{ob})$. We notice, of course, that the title of the text that he cites is the Chinese Document and not the Origin of the Sandalwood Statue which Resides in China! 'Gos Lo tsā ba's first and major critic was Grwa phug pa Lhun grub rgya mtsho (c. 1400-c. 1460), and the latter mentions this reference to the chronology proposed by the narrative of the sandalwood statue in his detailed, seminal work on Kälacakratantra calendrical astronomy of 1447 (see Grwa phug pa Lhun grub rgya mtsho (1681, 3a-b) and Grwa phug pa Lhun grub rgya mtsho $(2002,3)$, which became the tested standard of the so-called Phug Tradition (phug lugs) of Tibetan calendrical astronomy. Notwithstanding the fact that an interlineary note in his work even mentions a 'chronology of the sandalwood lord' (tsandan jo bo'i lo rgyus), neither he nor 'Gos Lo tsā ba seems to have been directly familiar with the Origin of the Sandalwood Statue which Resides in China, a work that, as we now know, was to become part of the canon. To be sure, the absence of the Origin of the Sandalwood Statue which Resides in China from the early Tanjur catalogues and its obvious felt presence in the first half of the fourteenth century does not necessarily mean that it, or its basic narrative, was not more widely known prior to this time. Indeed, we meet with an early, if not what is so far the earliest, Tibetan mention of a work that deals with the history of this statue in the biography of Ze'u 'Dul 'dzin Grags pa brtson 'grus (1253-1316), alias Ze'u dpag shi (< Mon. baysi), that is, 
Master Ze'u - Ze'u 'Dul 'dzin was one of the resident chaplains who were active at the courts of Qubilai and Ölǰeitü (Chengzong, r. 1294-1307). Upon his return to Central Tibet, he ultimately served as Snar thang monastery's 1oth abbot from 1305 until his death. Written in an optically not unpleasant variety of the dbu med script, a manuscript of this relatively short biography is happily in my possession. Not only is it anonymous, it is also undated. However, judging from the contents, I believe it can be reasonably argued that the author must have been one of his disciples. It contains much that should be of importance to students of Snar thang monastery. It is also worthy of note that the author mentions a certain Rin chen grags, whose name he prefixes with imperial preceptor (ti shri< Ch. dishi 帝師) (see Unknown?, 17b). ${ }^{27}$ We know that the affixation of the 'imperial preceptor' title does not necessarily mean that the court had officially granted him this title. For example, Karma pa III is often associated with this epithet, but we know with certainty that he never actually held this office, as Tshal pa implies in his sketch of the Karma pa's life in the Deb ther dmar po when he writes, in an entry for the year 1337, how the Karma pa argued in the presence of officials that included the then Imperial Preceptor for a reinstatement of the privileges that high-level government officials had earlier taken away from a large portion of the Chinese and the Tibetan Buddhist clergy of Amdo, owing to their misbehaviour. ${ }^{28}$

In fact, during the Karma pa's sojourn in Yuan China from 1332 to 1334 and then again from 1337 to his passing, Kun dga' rgyal mtshan (1310-1358) was the only Sa skya pa lama of the 'Khon family who was the actual imperial preceptor and who therefore held the official seal of this office. Kun dga' rgyal mtshan reigned as imperial preceptor from 1333 to 1358 and Kun dga' legs pa'i 'byung nas rgyal mtshan dpal bzang po (1308-1329) was his predecessor and a member of the same 'Khon family. Thus, it would appear that this Rin chen grags, whose family origins were definitely not connected to that branch of the 'Khon family that ruled over Sa skya, was an interim, acting imperial preceptor without officially holding this office and its seal. Rin chen grags is so far known from three different Tibetan sources, where he is noted in passages that discuss events of c. 1314 (for details, see van der Kuijp 2004, 39, 43-6). On the other hand, three Chinese sources suggest that he or his namesake temporarily filled the role of imperial preceptor from 1329 to 1333 (van der Kuijp 2004, 43-6). This would

\footnotetext{
27 See Unknown $(?, 17 \mathrm{~b})$.

28 Tshal pa Kun dga' rdo rje (1981, 104-5); see also Tshal pa Kun dga' rdo rje (1988, 91-2). An expanded narrative of this incident is found in dPa' bo II gTsug lag phreng ba (1986, $941-2)$.
} 
mean that the reference to him as dishri in the Tibetan sources is anticipatory, as would be its occurrence in Ze'u 'Dul 'dzin's biography.

In a passage that appears in Ze'u 'Dul 'dzin's biography prior to the notice of his invitation by Qubilai, we come across a rather substantial passage on the fortunes of the sandalwood statue that ends in an interesting twist (Unknown?, 9a-10b). We are told that, intending to be kind to his mother, the historical Buddha travelled to the land of the gods when he was 38 years old to teach her dharma, and that he stayed there for three summer months. King Udayana [sic] thought about him and requested Maudgalyāyana, one of his main disciples, to construct a statue of the Buddha. Maudgalyāyana took 32 artisans and a chunk of red sandalwood to the land of the gods and, after the statue had been made, went back to the land of mankind. The Buddha himself returned to the land of mankind at the end of the three summer months that, as we are now told, occurred in the iron-hare year $[c .799 \mathrm{BC}] .{ }^{29} \mathrm{He}$ then paid the statue his respects and, placing his hands on it, foretold that it would arrive in China 1000 years after his nirvana; it would benefit the gods and humankind; then (Unknown?, 10a-b):

tsan dan gyi sku'di bzhengs nas chu phag lo yan chad la lo chig stong dgu brgya lnga bcu rtsa gsum lon pa yin / 'dii lugs kyi [read: kyis] bcom ldan 'das mya ngan 'das nas chu phag lo yan chad la lo chig stong dgu brgya dang bcu gcig lon pa yin / shing +stagzla ba bzhi pa'i tshes brgyad la sangs rgyas sku bltam[s] / bcu dgu lon nas khyim dor te gangs kyi ri la dka' ba mdzad/sum bcu la sangs rgyas / mos pa skye ba'i [read: bskyed pa'i] byung tshul ngo mtshar can 'di lcang ra ba shag seng gis rgya nag cong rdor bris pa / kun + mkhyenmchims kyi phyag yig 'dug pa la bris pa'o //

Up to the water-pig year [1263], one thousand nine hundred and fiftythree years have elapsed since this sandal wood statue was created. According to the position of this [account], up to the water-pig year, one thousand nine hundred and eleven years elpased since Lord's nirvana. The Buddha was born on the eighth day of the fourth month of the wood[-tiger] year [c. $837 \mathrm{BC}]$. Having reached the age of nineteen, he left home and practised austerities among the snowy mountains; he became a Buddha at the age of thirty. This marvellous story that arouses respect, which was written in China's Cong rdo (<Ch. Zhongdu 中都) ${ }^{30}$ by lCang

29 This detail is absent from the Tibetan canonical account; see above n. 20.

30 Among other instances, Tibetan cong to also occurs in several colophons of the writings of 'Phags pa Blo gros rgyal mtshan (1235-1280), Qubilai's first Imperial Preceptor; 
ra ba Shag (< Shākya) seng [ge], was the handbook of the All[-knowing] mChims (?Nam mkha' grags, 1210-1285); it is written.

I cannot identify this Lcang ra ba Shākya seng ge. mChims Nam mkha' grags he is usually referred to as the 'All-knowing mChims' - is of course most probably the famous and prolific scholar who was Snar thang monastery's seventh abbot.

In his undated narrative of the origin and the vicissitudes of the statue, and the merit that can be accrued when circumabulating it (he calls it a sacred statue proper, 'bur sku, as opposed to a drawn or painted sacred figure, bris sku) Lcang skya III Rol pa'i rdo rje (1717-1786) points out that he follows the Chinese accounts. ${ }^{31}$ The Tibetan accounts of the sandalwood statue in the 'Dul ba lung and the Drin lan bsab pa'i mdo, ${ }^{32}$ etc., that are contained in the Kanjurcanon, he writes, are but piecemeal and fragmentary, and do not give the entire picture; and he hastens to point out at the outset of his study of the fortunes of the sandalwood statue that there are many differences of opinion about the Buddha's year of birth among Chinese, Indian and Tibetan scholars and that there is much uncertainty about its chronology.

Pelliot may have been the first in the Western world to make the observation that the Hanlin 翰林 scholar Cheng Jufu 程鉅夫 (1249-1318) authored a stele-inscription with the title Zhantan foxiang ji 旃檀佛像記, Notes on the Sandalwood Statue of the Buddha (sometimes referred to as the Chijian zhantian ruixiang dianji 敕建斿檀瑞像殿記, Uyghur Record of the Sandalwood Statue), which is contained in the various editions of his collected essays. ${ }^{33}$ It is cited in toto in the 1333 Fozu lidai tongzai 佛祖歷代通載, Comprehensive History of the Buddhist Patriarchs, of Nianchang 念常 (1282-1341) and it was also used by Kangxi for the stele inscription of $1721 .{ }^{34}$ Cheng's work is not expressly dated,

see Ishihama and Fukuda $(1986,54,56)$. One of the capital cities of the Jurchen-Jin 金 Dynasty (1115-1234), Zhongdu is located in the southwestern part of present-day Beijing.

31 For what follows, see Lcang skya Rol pa'i rdo rje $(1995,657)$.

32 For the first, see the story of King Udrāyana in the Vinayavibhanga, which was studied in Nobel (1955). For the second, the full title of which is Thabs mkhas pa chen po sangs rgyas drin lan bsab pa'i mdo, see Sde dge (1991, vol. 16, no. 353 [\# 353], 461/3-493/2 [Ah, $106 \mathrm{a}-197 \mathrm{~b}])$. This sutra was translated from the Chinese. It is listed in the Lhan dkar ma catalogue of 812 or 824 , but not in the possibly somewhat later 'Phang thang ma one; see Lalou (1953, 325, no. 253).

33 For the text in the most recent edition of his oeuvre, see Cheng (2009, 98-9).

34 See, respectively, Nian Chang (1344, 73ob26-731b2) and Franke and Laufer (1914, Plate 26). The latter is a truncated, trilingual piece in Chinese, Manchu and Mongol, that goes up 
but 1289 is the last year that he mentions, so that it may very well be based on the earlier work that is dated 1263 and cited by Ze'u 'Dul 'dzin.

No doubt in accordance with a reverse calculation (ldog rtsis) using the [incomplete] (grub rtsis [< grub mtha'i rtsis], siddhāntajyotiśa) of the Kälacakratantra corpus, the colophon of the rGya rtsis chen mo observes that exponents of the Phug pa tradition had ascertained that the Buddha passed away on the fifteenth day of the fourth lunar month of the iron-dragon year. Indeed, it is in Grwa phug pa's work that we first encounter this year of the Buddha's nirvana, which works out to be $c .881$ BC. ${ }^{35}$ Having stated that 'Jam dbyangs [Mañjuśrí] was born 44 years thereafter, in the water-male-rat year [c. 837 BC], 'Jam dbyangs bzhad pa'i rdo rje IV writes:

'jam dbyangs 'khrung [read: 'khrungs] nas lo nyis stong bzhi brgya go bzhi song ba na bde skyid rgyal pos sngar gyi rtsis gzhung bcos bsgyur byas nas rgya rtsis chen mo shog grags brgya brgya lhag spel nyid kyis bka' bzhin rgya sog bod kyi yi ger bkod du bcug /

When two thousand four hundred and ninety-four years had expired since *Mañjuśri's birth, in accordance with the order by emperor bDe skyid [Kangxi]: "Disseminate the more than hundreds of pages of the rGya rtsis chen mo after having edited and translated an earlier treatise of mathematical astronomy!" it was committed to Chinese, Mongol and Tibetan writing.

\section{That is all.}

No doubt imitating illuminated Sanskrit manuscripts, ${ }^{36}$ Tibetan xylographs with a variety of adornments and illustrations are probably as old as the printing of Tibetan textual material itself, from tablets with dhäranīincantations to entire works, the earliest specimen of which appears to date from around the year 1200 . The quality of the original drawings and their subsequent carving varies greatly; some are rather primitive and coarse, others are quite gorgeous and obviously executed with great care and attention to detail. Non-dhärani texts in tablets and boxes appear in xylographs at least as early as the first half of the eighteenth century. The recent publication of the Mongol text of the

to the 63rd year of Kangxi's reign, although the text of the inscription itself was prepared during his 6oth year, that is, 2711 years after the passing of the historical Buddha! rgya mtsho (2002, 85-90).

$36 \operatorname{Kim}(2013)$ is a recent contribution to their study. 
Tengri-yin $u d q$ - $a$ was given a print-run of 500 copies; the Tibetan text of the Rgya rtsis chen mo awaits a modern publication and I have nowhere come across a record of how many xylograph copies were made from the printing blocks. Lastly, let us take a look at the ways in which these Mongol and Tibetan xylographs reproduced some important diagrams. The first appears to be the celestial globe, which Verbiest created in 1673. A plate of this globe is reproduced in Needham [with Wang] and we have similar diagrams, actually several of these, in the Tengri-yin udq- $a$ and the Rgya rtsis chen mo. ${ }^{37}$ The latter two also have a fine star map and numerous diagrams of individual constellation. ${ }^{38}$

A final note: the nineteenth century witnessed xylographs of at least two works that beg our attention for their special and perhaps unique features. The first of these is the xylograph of the tour de force of a work by Klong chen Chos dbyings stobs ldan rdo rje (? $1785^{-1848)} \cdot{ }^{39}$ Mainly active in the Re skong region of Amdo and especially associated with Ko'u sde dgon Rdzogs chen rnam rgyal gling, ${ }^{40}$ this author wrote a fascinating versified work titled $m D$ o rgyud rin po che'i mdzod at the age of 51 [50] in the earth-male-dog year [?1838], to which he added a summary, a word-for-word commentary at the age of 53 [= 52$]$, an extensive commentary subtitled Tshangs chen bskal pa mdzes pa'i rgyan, and one entire volume of illustrations. ${ }^{41}$ This encyclopaedic work is indeed a significant forerunner of Kong sprul Blo gros mtha' yas' (1813-1899) much better known and written in a somewat different register, the Shes bya ba mdzod and autocommentary of 1864 . The last volume of Klong chen Chos dbyings stobs ldan rdo rje's commentary contains a large number of carefully executed illustrations (dpe'u ris) with explanatory glosses as well as the reproduction of the xylograph of the first part titled mDo rgyud rin po che'i mdzod kyi gnas dang po thun mong mdo yi dpe'u ris zla ba'i phreng ba mchan dang 'grel dang bcas pa (Klong chen Chos dbyings stobs ldan rdo rje 2000, vol. 5).

Another interesting, albeit somewhat coarse, specimen of nineteenthcentury xylography must certainly be the undated illustrated material medica

37 See, respectively, Needham [with Wang] (1970, 388, fig. 176), Fig. 94, beween pp. 250 and 251; Čeden (1990, 722ff.) and the Rgya rtsis chen mo, vol. pha, fol. $2 \mathrm{a}$ (gong)/ Juan 22, fol. 2a (shang), vol. ba, fols. 2aff. / Juan 23, fols. 2aff.

38 Čeden (1990, 896) and the Rgya rtsis chen mo, vol. Sa, fol. 1a-2a / Juan 32, 1a-2a; see also Needham [with Wang] (1970, 250-51, fig. 94).

39 For a capsule study of his life, see Nyoshul Khen po (2005, 4007-8).

40 For this monastery, see Lce nag tshang Hūm chen and Ye shes 'od zer sgrol ma (2004, 70-106) and Reb gong pa 'Jigs med bsam grub (2013, 581-5).

41 I have seen xylographs from the original woodblocks, which were handsomely printed in modern book form in Klong chen Chos dbyings stobs ldan rdo rje (2000). This work is apparently being translated into English. 
of 'Jam dpal rdo rje in which we find, inter alia, lovingly, but somewhat amateurishly, carved illustrations of various medical substances plus most of their nomenclature in Tibetan (cephalic, dbu can), Chinese, Mongol and Manchu scripts ([Dge bsnyen]'Jam dpal rdo rje (1971a;2008a)).'Jam dpal rdo rje also composed illustrations to De'u dmar dGe bshes bsTan 'dzin phun tshogs' (1673-?) Dri med shel phreng material medica of 1727 , in which he also often included a quadrilingual gloss of the names of various drugs, medical instruments, etc. ([Dge bsnyen] 'Jam dpal rdo rje (1971b; 2008b)). According to its colophon, the carving of the printing blocks of this work was completed on the eighth day of the sixth month of the iron-female-pig year (1851), that is, "the third [regnal] year (gnam lo) of the 'Great Mañjuśrī Emperor Shwan thung $(<$ Ch. Xianfeng 咸豐, r. 1850-1861)'” This means that we have here a slight chronological problem that, however, I cannot solve at this time!

\section{References}

\section{Tibetan References}

Blo bzang sbyin pa. 2003. Bla brang dus 'khor ba smad sog badzra gyi gsung 'bum, Pod gsum pa [vol. 3. Ed. 'Brug rgyal mkhar. Lanzhou: Kan su'u mi rigs dpe skrun khang. Brag dgon Zhabs drung dKon mchog bstan pa rab rgyas. 1982. mDo smad chos 'byung.

Ed. Smon lam rgya mtsho. Lanzhou: Gan su'u mi rigs dpe skrun khang.

bSam grub rgya mtsho. 1992. Skar rtsis kun 'dus nor bu, edited by Rdo rje rgyal po.

Beijing: Krung go'i bod kyi shes rig dpe skrun khang.

Dalai Lama v Ngag dbang blo bzang rgya mtsho. 1991. Ngag dbang blo bzang rgya mtsho'i rnam thar, vol. 3. Lhasa: Bod ljongs mi dmangs dpe skrun khang.

Dor zhi, ed. 1988. Lang jus sde bzhi sogs kyi dkar chag phyogs bsgrigs. Lanzhou: Kan su'u mi rigs dpe skrun khang: $1-58$.

dPa' bo II gTsug lag phreng ba. 1986. Chos 'byung mkhas pa'i dga' ston, Smad cha [vol. 2], edited by rDo rje rgyal po. Beijing: Mi rigs dpe skrun khang.

Fan Baoliang 焚保良 and Shui Tianchang 水天长. 2009. Byang ngos sprul pa'i sder gros su btab pa mkhas pa mgu bai gtam. Translated by rGya ye chos 'phel. Lanzhou: Kan su'u mi rigs dpe skrun khang.

gDong drug bsnyems pa'i lang tsho. 1983. Catalogue of the Peking Tanjur. Repr.

L. Chandra. New Delhi: International Academy of Indian Culture.

'Gos Lo tsā ba gZhon nu dpal. 1466. Rtsis la 'khrul pa sel ba. Sne'u gdong/Rtsed thang xylograph: 49 folios.

Grags pa, ed. 1995. Bod kyi bstan bcos khag cig gi mtshan byang dri med shel dkar phreng ba. Xining: mTsho sngon mi rigs dpe skrun khang. 
Grwa phug pa Lhun grub rgya mtsho. 1681. dPal dus kyi 'khor lo las 'byung ba'i rtsis kyi tshul la yang dag pa'i ngag sbyin pa legs par bshad pa padma dkar po'i zhal lung. Lhasa Zhol xylograph: 245 folios.

2002. Rtsis gzhung pad dkar zhal lung, edited by Yum pa. Beijing: Mi rigs dpe skrun khang: $1-362$.

Gung thang III dKon mchog bstan pa'i sgron ma. 1971. Dus gsum rgyal ba'i spyi gzugs rje btsundkon mchog 'jigs med dbang po'i zhal snga nas kyi rnam par thar pa rgyal sras rgya mtsho'i 'jug ngogs. Collected Works, vol. 1 [Ka]. New Delhi: Ngawang Gelek Demo.

1990. Kun mkhyen 'jam dbyangs bzhad pa sku 'phreng gnyis pa rje 'jigs med dbang po'i rnam thar. Ed. mKha' 'gro skyabs. Lanzhou: Kan su'umi rigs dpe skrun khang.

Huang Mingxin 黃明信 and Chen Jiujin 陈久金. 1987. Bod kyi rtsis rig gi go don dang de’i lag len / Zangli de yuanli yu shijian 藏历的原理与实践. Beijing: Mi rigs dpe skrun khang.

'Jam dbyangs bzhad pa'i rdo rje IV Skal bzang thub bstan dbang phyug. nd. Rgya rtsis chen po bstan rtsis mdor bstan gsal ba'i me long, Collected Works, vol. Cha [5]. Bla brang bkra shis 'khyil xylograph: 3 folios. Tbrc.org, WMDL13.

'Jam dpal rdo rje. 1971a. An Illustrated Tibeto-Mongolian Materia Medica of Ayurveda.

Repr. L. Chandra. New Delhi: International Academy of Indian Culture: 1-347.

- 1971b. An Illustrated Tibeto-Mongolian Materia Medica of Ayurveda. Repr.

L. Chandra. New Delhi: International Academy of Indian Culture: fols. 1-47.

dGe bsnyen 'Jam dpal rdo rje. 2008a. gSo byed bdud rtsi'i 'khrul med ngos 'dzin bzo rig me longdu shar ma mdzes mtshar mi rgyan. Ed. mTsho sngon zhing chen bod kyi gso rig zhib 'jug khang. Arura, vol. 065. Beijing: Mi rigs dpe skrun khang: 1-325.

2008b. Dri med shel phreng nas bshad pa'i sman gyi 'khrungs dpe mdzes mtshar mi rgyan. Ed. mTsho sngon zhing chen bod kyi gso rig zhib 'jug khang. Arura, vol. 065. Beijing: Mi rigs dpe skrun khang: 329-491.

Jaya Paṇịita Blo bzang 'phrin las dpal bzang po. 1981a. Zab pa dang rgya che ba'i dam pa’i chos kyi thob yig gsal ba'i me long, Collected Works, vol. 4. Repr. L. Chandra. New Delhi: International Academy of Indian Culture.

— 1981b. Rje btsun dam pa blo bzang bstan pa'i rgyal mtshan dpal bzang po'i thun mong ba'i rnam thar bsdus pa, Life and Works of Jicundampa I. Repr. L. Chandra. New Delhi: International Academy of Indian Culture.

Khams sprul IV bsTan 'dzin chos kyi nyi ma. 1976. Rgyan gyi bstan bcos me long pan chen bla ma'i gsung bzhin bkral ba dbyangs can ngag gi rol mtsho legs bshad nor bu'i 'byung khungs. New Delhi: Kunzang Tobgey.

Klong chen Chos dbyings stobs ldan rdo rje. 2000. mDo rgyud rin po che'i mdzod [kyi rtsa ba /kyi bsdus don dpag bsam 'khri shing/kyi 'bru 'grel/kyi rgyas 'grel/kyi dpe'u ris], vols. 5. Ed. Tshe ring bkra shis et al. Chengdu: Si khron mi rigs dpe skrun khang. 
Lcang skya Rol pa'i rdo rje. 1995. Tsan dan jo bo’i lo rgyus bskor tshad phan yon mdor bsdus rin po che'i phreng ba. Collected Works, vol. Ja. Beijing: Krung go bod brgyud mtho rim nang bstan slob gling nang bstan zhib 'jug khang: 653-672.

Lce nag tshang Hūṃ chen and Ye shes 'od zer sgrol ma. 2004. Reb kong sngags mang gi lo rgyus phyogs bsgrigs. Beijing: Mi rigs dpe skrun khang.

Reb gong pa 'Jigs med bsam grub. 2013. mDo smad reb gong lo rgyus chen mo ngo mtshar gtam gyi bang mdzod. Beijing: Mi rigs dpe skrun khang.

Rgya rtsis chen mo. 1715. Beijing xylograph.

Sde srid Sangs rgyas rgya mtsho. 1996. Snyan 'grel dbyangs can dgyes glu'i mchan 'grel, edited by Sangs rgyas et al. Xining: mTsho sngon mi rigs dpe skrun khang.

Sde dge. 1991. The Tibetan Tripițaka, Taipei Edition, vols. 72. Ed. A. Barber. Taipei: ScM Publishing, Inc.

Shes rab chos 'phel. 1989. Ma hà tsi na'irtsis gzhung 'jam dpal dgyes pa'i mchod sprin, ed. 'Brug rgyal mkhar. Lanzhou: Kan su'u mi rigs dpe skrun khang.

Tshal pa Kun dga' rdo rje. 1981. Ed. Dung dkar Blo bzang 'phrin las. Beijing: mi rigs dpe skrun khang.

Unknown. ?. dPal ldan ze'u 'dul 'dzin chen po'i rnam thar gsal byed yid bzhin nor bu, dbu med manuscript: 21 fols.

Yum pa. 1998. "Rgya rtsis bod du dar tshul cung zad bshad pa shel dkar me long." Bod kyi rtsis rig kun 'dus chen mo, vol. 1. Ed. Byams pa 'phrin las et al. Chengdu: Si khron mi rigs dpe skrun khang: 556-67.

\section{Chinese References}

Brag dgon Zhabs drung dKon mchog bstan pa rab rgyas. 1989. Anduo zhengjiao shi 安多政教史. Tr. Wu Jun 吳均 et al. Lanzhou: Gansu minzu chubanshe.

Cheng Jufu 程鉅夫. 2009. Cheng Jufu ji 程鉅夫集. Ed. Zhang Wenshu 張文澍. Changchun: Ji lin wenshi chubanshe.

Fan Baoliang 樊保良 and Shui Tianchang 水天长. 1997. Kuodan yu Saban liangzhou huitan 阔端与萨班凉州会谈. Lanzhou: Gansu minzu chubanshe.

Huang Mingxin 黃明信 and Chen Jiujin 陈久金. 1987. Bod kyi rtsis rig gi go don dang de'i lag len / Zangli de yuanli yu shijian 藏历的原理与实践. Beijing: Mi rigs dpe skrun khang.

Nian Chang 念常. 1333. Fozu lidai tongzai 佛祖歷代痛載. Taishō shinshō daizōkyō 大正新脩 大蔵経, ed. Takakusu Junjirō 高楠順次郎 and Watanabe Kaikyoku 渡辺海旭. Tokyo: Taishō issaikyō kankōkai, 1924-32: vol. 49, no. 2036, $73 \mathrm{ob} 26-731 \mathrm{~b} 2$.

Pan Nai 潘䍏, comp. 2009. Chongzhen lishu: Fu xiyang xinfa lishu zengkan shizhong 崇禎曆書: 附西洋新法曆書增刊十種. 2 vols. Shanghai: Shanghai guji chubanshe. 
Tshal pa Kun dga' rdo rje. 1988. Hongshi 紅史. Tr. Chen Qingying 陳庆英 and Zhou Runnian 周润年. Lhasa: Xizang renmin chubanshe.

Wu Kunming 伍昆明. 2009. Zaoqi chuanjiaoshi jinzang huodong shi 早期传教士 进㫌活动史. Beijing: Zhongguo zangxue chubanshe.

\section{Mongol References}

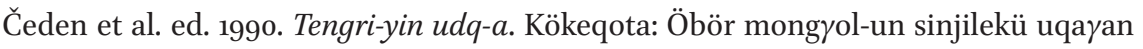
teknik mergejil-ün keblel-ün qoriy-a.

Qitad-un jiruqai-yin sudur. 17??. Beijing xylograph.

\section{Other References}

Baumann, B. 2008. Divine Knowledge. Buddhist Mathematics According to the Anonymous Manual of Mongolian Astrology and Divination. Leiden: Brill.

Boyle, J. A. 1971. The Successors of Genghis Khan. New York: Columbia University Press. Charleux, I. 2006. Temples et monastères de Mongolie-intérieure. Paris: Éditions du Comité des traveaux historiques et scientifiques, Institut nationale d'histoire de l'art.

Chu Pingyi 柷平一. 2007. "Archiving knowledge: a life history of the Calendrical Treatise of the Chongzhen Reign (Chongzhen lishu)." Extrême-Orient, ExtrêmeOccident 1: 159-84.

Farquhar, D. M. 1990. The Government of China under Mongolian Rule, a Reference Guide. Münchener Ostasiatische Studien, Band 53. Stuttgart: Steiner.

Franke, O. and B. Laufer. 1914. Epigraphische Denkmäler aus China. Erster Teil. Lamaistische Klosterinschriften aus Peking, Jehol und Si-ngan, Mappe 1. Berlin: Dietrich Reimer.

Heimbel, J. 2013. "The Jo gdan tshogs sde bzhi: an investigation into the history of the four monastic communities in Śāktaśrībhadra's Vinaya Tradition.” In NepalicaTibetica. Festgabe für Christoph Cüppers, Band 1, edited by F.-K. Ehrhard and P. Maurer, 187-241. Andiast: International Institute for Tibetan and Buddhist Studies.

Hosten, H., s.J., ed. and tr. 2011. A Missionary in Tibet, 1713-1721: Letters and Other Papers of Fr. Ippolito Desideri, s.J. Kolkata: R. N. Bhattacharya.

Ishihama Yumiko and Fukuda Yoichi. 1986. A Study of the Grub mthah of Tibetan Buddhism, vol. 4. On the Chapter on the History of Mongolian Buddhism of Thuhu bkwan's Grub mthah. Studia Tibetica, No. 11. Tokyo: The Toyo Bunko.

Jami, C. 2012. The Emperor's New Mathematics: Western Learning and Imperial Authority during the Kangxi Reign (1662-1722). New York: Oxford University Press.

Karmay, S. G. 2003. The Diamond Isle. A Catalogue of Buddhist Writings in the Library of Ogyen Choling, Bhutan. Wiener Studien zur Tibetologie und Buddhismuskunde, 
Heft 56. Vienna: Arbeitskreis für Tibetische und Buddhistische Studien Universität Wien.

Kim Jinah. 2013. Receptacle of the Sacred: Illustrated Manuscripts and the Buddhist Book Cult in South Asia. Berkeley, CA: University of California Press.

van der Kuijp, L. W. J. 2004. The Kālacakratantra and the Patronage of Tibetan Buddhism by the Mongol Imperial Family. Ed. F. Venturi. Bloomington, In: Department of Central Eurasian Studies, Indiana University.

- 2013. "Some remarks on the textual transmission and text of Bu ston Rin chen grub's Chos 'byung, a Chronicle of Buddhism in India and Tibet." Revue d'Etudes Tibétaines 25: 115-93.

Lalou, M. 1953. "Les textes Bouddhiques au temps du roi Khri srong lde btsan." Journal asiatique 261: 313-51.

MacDonald, A. 1963. "Préambule à la lecture d'un Rgya-bod yig-chan்." Journal asiatique 251: $53^{-159}$

Martzloff, J.-C. 1993-1994. "Space and time in Chinese texts of astronomy and of mathematical astronomy in the seventeenth and eighteenth centuries." Chinese Science 11: 66-92.

Needham, J. [with Wang Ling]. 1970. Science and Civilization in China, vol. 3: Mathematics and the Sciences of the Heavens and the Earth. Cambridge: Cambridge University Press.

Nobel, J. 1955. Udrayāṇa, König von Roruka. Eine buddhistische Erzählung. Vols. I, II. Wiesbaden: Otto Harrassowitz.

Nyoshul Khen po Jamyang dorjé. 2005. A Marvelous Garland of Rare Gems. Biographies of Masters of Awareness in the Dzogchen Lineage. Tr. R. Barron. Junction City, CA: Padma Publishing.

Pelliot, P. 1914. Untitled book review. Journal asiatique: Onzième Série, Tome IV: 188-90.

Pomplun, T. 2010. Jesuit on the Roof of the World. Ippolito Desideri's Mission to Tibet. New York: Oxford University Press.

2011. "Natural Reason and Buddhist Philosophy: The Tibetan Studies of Ippolito Desideri, sJ (1684-1733)." History of Religions 50: 384-419.

Sagaster, K. 1967. Subud Erike. Ein Rosenkranz aus Perlen. Die Biographie des 1. Pekinger IČan் skya Khutukhtu Nag dbai் blo bzan் č'os ldan, verfaßt von Nag dban் čos ldan alias Šes rab dar rgyas. Asiatische Studien, Band 20. Wiesbaden: Otto Harrossowitz.

Schuh, D. 2012. "Kleine Enzyklopädie zur Tibetischen Mathematik, Kalenderrechnung und Astronomie (skar rtsis) sowie zu den Sinotibetischen Divinationskalkulationen (nag rtsis)." In Contributions to the History of Tibetan Mathematics, Tibetan Astronomy, Tibetan Time Calculation (Calendar) and Sino-Tibetan Divination, vol. IV. Andiast: International Institute of Tibetan and Buddhist Studies. 
Seyfort Ruegg, D. 1991. "Mchod yon, yon mchod and mchod gnas/yon gnas: On the Historiography and Semantics of a Tibetan Religio-Social and Religio-Political Concept." In Tibetan History and Language. Studies dedicated to Uray Géza on His Seventieth Birthday, edited by E. Steinkellner, 441-53. Wiener Studien zurTibetologie und Buddhismuskunde, Heft 26. Wien:Arbeitskreis fürTibetische und Buddhistische Studien Universität Wien.

1995. Ordre sprituel et ordre temporel dans la pensée bouddhique de l'Inde et du Tibet. Publications de l'Institut de Civilisation Indienne, Fasc. 64. Paris: ÉditionDiffusion de Boccard.

Sivin, N. 1973. "Copernicus in China." Studio Copernicana 6: 1-53. 1995. Science in Ancient China. Aldershot: Variorum.

Sørensen, P. K. 1986. A Fourteenth Century Tibetan Historical Work. Rgyal-rabs gsal-ba'ime-lon. Author, Date and Sources. A Case-Study. Copenhagen: Akademisk Forlag. 1994. Tibetan Buddhist Historiography. The Mirror Illuminating the Royal Genealogies. An Annotated Translation of the XIVth Century Tibetan Chronicle: rGyalrabs gsal-ba'i me-long. Asiatische Forschungen, Band 128. Wiesbaden: Otto Harrassowitz.

Stein, R. A. 1966. "Nouveaux documents Tibétains sur le Mi-ñag/Si-hia." In Mélanges de Sinologie offerts à Monsieur Paul Demiéville, vol. I, 281-9. Bibliothèque de l'Institut des Hautes Études Chinoises, vol. xx. Paris: Presses Universitaires de France.

Sweet, M. J. 2006. “Desperately seeking Capuchins: Manoel Freyre's Report on the Tibets and their Routes (Tibetorum ac eorum Relatio Viarum) and the Desideri Mission to Tibet." Journal of the International Association of Tibetan Studies 2: 1-33. Online at: www.jiats.org.

2010. Mission to Tibet. The Extraordinary Eighteenth-Century Account of Father Ippolito Desideri, s.J. edited by L. Zwilling. Boston: Wisdom Publications. 